\title{
Education - School Financing and University Reform
}

\begin{abstract}
This chapter tells the story of how Georgia's government reformed higher education in Georgia by diverting the flow of financing from institutions, such as schools and universities, to customers, i.e., students and their parents. Prior to the reform, many institutions were underfunded, and almost all teachers were underpaid. Under the new scheme, students were given vouchers that could be redeemed at any school. This created healthy competition among providers, and it improved the quality of education dramatically. Additionally, a system was put in place under which government bonuses were awarded for performance, as measured by student achievements in university entrance exams and school final exams, as well as for teacher proficiency and certification. The chapter concludes with a discussion of the plan to establish an American University in Georgia.
\end{abstract}

Keywords Education - School system - Exams - Computer-aided tests $(\mathrm{CAT}) \cdot$ Voucher-based

\subsection{School Reform - Diverting the Flow of Financing from Schools to STudents}

Education reform is frequently neglected by politicians, simply because any given cohort of students will see several election cycles before they leave the system. In Georgia, many schools were underfunded, and almost all teachers were underpaid in the early 2000s. As a result, degrees

(C) The Author(s) 2017

N. Gilauri, Practical Economics, DOI 10.1007/978-3-319-45769-7_10 
and diplomas were for sale to the highest bidder. In response, the new government diverted the flow of financing: from schools to students and their parents. Students were given vouchers that could be redeemed at any school. This created healthy competition among providers, and it improved the quality of schooling dramatically. Additionally, a bonus system was put in place to reward schools for good performance.

\subsubsection{The Long Haul}

No country can prosper for any length of time without making continuous improvements and upgrades to its education system. Teachers are, perhaps, the most important enablers of a better future in any country. They are also opinion leaders in almost all developing countries, on par with medical doctors. For a lot of people, especially in rural areas, teachers are the incarnation of authority. Says J.D. Salinger: "You can't stop a teacher when they want to do something. They just do it." ${ }^{\text {A }}$ At the same time, many teachers are politically very active. This means that any reform of the education system in a developing country almost automatically leads to political turmoil.

To make things even more difficult, it takes a long time until education reform yields visible effects. Reforms in most other areas have a much shorter lead time, a clear political advantage. Typically, almost any reform initially faces more opposition than support. Most people get attached to the status quo, be it good or bad. To win the favor of these people, reformers need to produce positive results quickly, ideally within a year or two. But it takes a decade for education reform to deliver real, initial results. This timeframe exceeds the average political cycle by a factor of two. As a result, politicians are reluctant to tackle education reform: most teachers won't like the changes, whatever they may be, and those who benefit won't feel the advantages the reform brings until it's too late for those who introduce the changes to bring in the harvest. As a result, transforming the education system is arguably one of the biggest political challenges of all, in developing as well as developed countries.

\subsubsection{Bribes over Brains}

To graduate from school with good grades and be accepted by a university in pre-reform Georgia, students needed money and connections, rather 
than brains or hard work. This was due to two fundamental flaws in Georgia's school system in the early 2000s: teachers were generally underpaid, and schools were generally overstaffed.

- Salaries for teachers were very low. As in many other areas of public service, this gave rise to widespread corruption. Teachers had no choice but to make money on the side to provide for themselves and their families.

- The number of teachers was too high. There simply were not enough other jobs, and being a teacher was better than being unemployed. Teaching may not have been well paid, but at least it came with a certain social status.

There were three types of teachers: good, bad, and independent. The good ones made additional income by giving private lessons after school and helping students prepare for exams. The bad ones made additional income by accepting bribes or gifts from parents in exchange for good grades. The independent ones, a very rare type, were those whose families were wealthy enough to let them pursue teaching as a calling. But generally, the pay was so low that most teachers were involved in some sort of illegal activity to make money on the side. As a result, it was virtually impossible even for a gifted, hard-working student to pass a university entrance exam without paying a bribe or taking advantage of personal connections, while underachievers from well-connected, wealthy families had no trouble getting accepted. The effect on the morale and motivation of a whole generation of young people was disastrous. Their dreams of a better future for themselves and for their country were crushed by corruption.

\subsubsection{Getting Started}

The Georgian government had to choose where to start the education reform process: At the primary level? In the secondary school system? At universities? In teachers' preparation courses? We started somewhere else with university entrance exams, the nexus of secondary schools and universities. It quickly became clear that it was the right choice. The reform produced fast results and gave the government political credit for further reforms. Most importantly, it got students to believe that they have a future, and that it pays to study and work hard, even if you don't have connections. Initially, however, the reform faced fierce opposition because 
the corrupt practices had provided many employees in the education system with illegal income for so many years. But since the victims of these practices were even more numerous than the beneficiaries, there was immediate and overwhelming support for this reform in the population. The government relieved universities of their right to hold entrance exams. To ensure that universities could not jeopardize the reform, no leakage of any information was to be tolerated. It worked. In line with international best practice, the government created an independent, central examinations center. All over the country, applicants took the same exams simultaneously. The year 2005 was the first year in which all students got into tertiary education institutions without paying bribes for better grades and having patrons in high positions make phone calls to admission officers. In the first year, almost nobody believed that it was actually a free and fair process. Because of the many years of bad experience, everybody suspected that everybody else got better grades than they deserved. But after the second year, the centralization of entrance exams was already one of the top-rated reforms. Students started to study at schools to prepare themselves for the exams and for a better future. Studies show that students from poor regions were the biggest winners of the reform. Later on, computer-aided tests (CAT) were introduced to make the process easier to administer, protect the results from manual interference, and gain even more trust.

\subsubsection{School Financing: Money Follows Students}

As a next step, the government tackled school financing. Before the reform, funding received by schools very much depedned on personal relations between school principles and Ministry of Education. Almost all parameters, even the number of teachers assigned to a given school, were pre-approved by the ministry. This system led to a vicious cycle of corruption. School directors shared their funds with the very government officials who green-lighted their budgets, a system that is still common today in many developing countries.

The reform was simple in essence. In the past, money had gone to the schools. In the future, money would go to students. Students and their parents were given total freedom to choose a school, be it public or private, anywhere in the country, regardless of the school district in which they lived. No regional assignments or privileges were given to any school. Every student received a voucher from the government, and the school 
chosen by the student would receive the cash value of the voucher from the state's education budget. Most students chose a school nearby, which is why most of the ensuing competition was regional. But in some cases, especially in cities, students flocked to a few reputable schools. To avoid overcrowding, the number of students that each school could accept was limited. This cap was based on the space the school had. First-year students were selected on a "first come, first served" basis. Electronic applications helped avoid corrupt deals. This reform created healthy competition among schools. Many schools hired better teachers because they realized that students and their parents followed the best teachers, and that funds would follow the students.

The most important feature of this reform was that students were allowed to take their vouchers not only to public schools but to private schools as well, and that budgetary funds were subsequently transferred to these private schools. Although the value of the voucher was too low to pay for an education at most private schools in full and needed to be topped up by students' parents, the overall effect was one of healthy competition. It gave rise to many high-caliber new schools. Over the course of less than three years, the share of private schools as a percentage of the total number of schools jumped from 1.5 percent to 14 percent.

To determine the value of a voucher for a given student, the Ministry of Education developed a special formula. Initially, there were three basic variations of the formula, depending on where the student lived: in an urban area, in a rural area, or in a mountainous area. This was to account for the fact that the cost of running a school is typically higher in rural and mountainous areas because of smaller average class sizes. Additionally, schools in the mountains have to deal with higher expenses for heating because of the cold winters. Had the value of the voucher been the same for everyone, schools outside urban areas would have been underfunded.

\subsubsection{The Black Hole}

Having the money follow customers, i.e., students and their parents, rather than institutions, was a key catalyst to reduce inefficiencies and drive improvements. Yet the new system faced three challenges, all of them related to the fact that the demand side of the school system was liberalized, but the supply side was not. While students were free to choose any school they wanted, schools were not able to adjust their offering to the shifting needs of students. 
- Overstaffing. School directors quickly realized that they could not afford to keep on teachers who were not productive. But at the time, it was difficult for schools to let anyone go. Most schools were still state-owned institutions, and school directors wanted the government to take responsibility for any lay-offs. A handful of schools, however, managed to adjust their staff numbers without external intervention. As a result, they were able to increase the salaries of high-performing teachers.

- Oversupply. In some urban areas, there were far too many schools relative to the number of students. Partly, this was due to demographic changes. But since some of these schools had been established for political reasons in the first place, or as part of corrupt deals sealed in the past, it was difficult to close them down. This part of the school reform was very unpopular, but it was indispensable to implement the reform without breaking the budget.

- Underfunding. Although the value of the voucher reflected different levels of operating cost, some schools were not sustainable based on voucher funding alone. This mostly affected schools in remote areas that were the only provider of higher education for miles around and could, hence, not be closed down, even if the number of students was very low. Such schools were designated as "deficit schools" and received additional financing from the Ministry of Education.

This last challenge increased over time. In the first year of the reform, only 20 percent of all schools were designated as so-called deficit schools. But two years later, more than 50 percent had been designated deficit schools. As soon as school directors realized that the "deficit school" designation gave them access to additional financing, they got creative and found ways to meet the criteria. For example, some directors simply hired new teachers, often their relatives and friends. Others launched costly renovation programs. And all of them came to the Ministry of Education in the middle of winter to request heating subsidies. How do you say no to children who are without heating in the middle of winter? The government had no choice but to provide additional direct funding from the budget. Unfortunately, these exceptions had a snowball effect. The more schools were awarded additional financing, the more came up with new emergencies in an illicit competition for funds on top of the value of the vouchers. A black hole had formed in the education budget, and it was growing. 


\subsubsection{Reforming the Reform}

After a little over two years, it became apparent that the reform was failing. It's not unusual. One-off reforms rarely work. The hallmark of successful transformations is continuous improvement. So the government devised further changes, effectively reforming the reform. As a first step, the formula used to calculate the voucher value was refined. The new formula recognizes a wide range of factors that influence the cost of schooling in a given student's area of residence, such as the size of the nearest school, its offering beyond the standard curriculum, and its location:

$$
V=b+\sum_{i=1}^{7} v i
$$

$V$ is the total cash value of the voucher. While $b$ is the base value (GEL 300 per student per year), summands $v_{1}$ through $v_{7}$ cover surcharges for operating cost, the number of students, curriculum development, inclusion education, school maintenance, remote locations, and teachers' bonuses.

Additional funds were set aside for voucher funding so that voucherbased payments would cover the cost of running any school. As a result, the special status of a "deficit school" was eliminated. From then on, no school director could go to the Ministry of Education for additional nonvoucher funding.

As a second step, the government decided to help school directors reduce the number of teachers. There had been far too many teachers, even before the initial reform. But because of the unhealthy competition among schools for additional funding from the "black hole," the number of teachers had ballooned to a ludicrous level. In 2010, the ratio of teachers to students in Georgia was one of the highest in the world. According to data gathered by the World Bank, there was one teacher for every nine students in Georgia in 2010. The global average that year was 25. Only four countries had even fewer students per teacher than Georgia: Bermuda, Kuwait, Liechtenstein, and San Marino. ${ }^{2}$ The extra teachers cost Georgia a fortune, caused systemic inefficiency, and had a negative impact on the motivation of good teachers. They had to go - a suicide mission for any government. And in fact, the first attempt to lay them off backfired.

The government had decreed that every teacher needed to be certified by 2014 . In order to be certified, every teacher would have to pass an exam. To motivate teachers to take the exam sooner rather than later, 
teachers were awarded special bonuses for passing the exam and additional bonuses for proven computer literacy and certified English language skills.

Why should a Georgian teacher of, say, biology have English language skills? The idea was simple. If you speak English, you can use international sources to keep abreast of developments in your discipline and help prepare students from a small country to make their way in the world. Ultimately, it's about widening one's horizon. Georgia had been occupied by Russia for many years. At the time, almost everybody over the age of 30 spoke Russian. In a situation like that, having a teacher who (also) speaks English is an important stepping-stone for students to develop an openminded worldview.

Despite its inherent logic, the decision to build English language skills into the certification and bonus scheme for teachers, as well as the very idea of certification itself, caused major political turmoil. The problem was not so much the carrot. The problem was the stick. Initially, teachers were allowed to take the certification exam only once, and if they failed, they were let go. Teachers took to the streets in protest, saying that they had worked as teachers for decades, helped raise generations of children, and should not lose their livelihood based on the result of a single exam. And they were right. The government reacted quickly and introduced a less restrictive certification scheme. Teachers now had the right to take the certification exam three times over the course of a two-year period. Additionally, every teacher was entitled to one free preparation course. Only teachers who failed the exam all three times were let go. Within two years of the introduction of this new regulation, the number of teachers went down by 25 percent, and no more complaints were heard. In fact, teachers who failed three times were so ashamed that they often chose to leave schools on personal grounds rather than waiting for their contracts to be annulled because of their lack of certification. This particular element of Georgia's school reform is a fine example of how a failing reform can be turned into a success story by swift and decisive adjustments to the initial plan.

In a third step, the government created a new motivational system for school directors. Every school was ranked according to the average achievements of its students in the new, centralized university entrance exams, or in final school exams - this later reform could only be implemented once centralized, computer-aided exams had been introduced throughout the country. Having schools administer exams locally would only have caused additional corruption. Using these existing indicators 
was not only easier, and more transparent, than introducing an additional assessment, it also reflected the number one pursuit of students and their parents: better performance in final school exams or university entrance exams. At the time, the ranking was already being published, and parents used this as a guide when picking schools for their children. As a result, high-performing schools attracted more students and received more voucher-based financing than their low-performing peers. To increase this effect, the government rewarded the directors of the top 10 percent schools with substantial bonuses, while the directors of the bottom 10 percent schools were laid off and replaced. As a next step, directors should have received additional funds to reward high-performing teachers, but this stage of the reform was not implemented.

Georgia's experience with a school's average performance in university entrance exams as the reference metric for performance-based funding was overwhelmingly positive. But not all countries have comparable entrance exams. Alternative indicators that can be used to assess a school's performance and provide corresponding rewards include schools' final exams, students' achievements in science olympics, essay-writing contests, or other competitive events overseen by independent institutions. Using such objective criteria will encourage school directors to invest as much of their funds as possible in the de facto quality of the education they provide, rather than in marketing or other non-core activities. This is relevant even in developed countries, where schools have a tendency to spend more money on advertising at the expense of teachers' salaries and school infrastructure.

\subsubsection{Results}

After many years of reforms, some mistakes, and a fair number of innovations, Georgia now has a highly efficient, results-oriented system of school financing:

- Funds follow students, not schools. This creates competition among schools to attract more students by providing a better education better teachers, better facilities, and better materials.

- Students are free to choose any school. The fact that vouchers can be redeemed at any school, disregarding school districts, including private schools, fosters the improvement of individual schools and creates even more competition. Teachers are motivated to grow 
professionally to qualify for employment at private schools that typically pay higher salaries than public schools.

- Schools receive bonuses for performance. Schools are assessed based on the performance of their students in university entrance exams. Directors of top-performing schools are given additional funds, while directors of low-performing schools are counselled to leave.

\subsubsection{Broken English}

Around the same time, the Ministry of Education also launched its campaign to increase the number of native speakers teaching English in Georgian schools. There were very few English teachers in Georgia to begin with, and their knowledge was theoretical, based on Russian textbooks, rather than practical experience. For a long time, Russian had been the only foreign language taught in Georgian schools. It was clear that Georgia needed a step change in this area to prepare its students for life in a globalized world with English as its de facto lingua franca.

The Ministry of Education ran a communication campaign to explain why learning English mattered, emphasizing that only students who speak English would eventually be able to compete with their peers in Singapore or the United States, and that English is the language they would need to tap into the rich resources of the internet. In parallel, the government launched a program to bring native speakers of English from the United States, Canada, the United Kingdom, and Australia to Georgia as volunteers. Their mission was, quite simply, to teach English to Georgia's English teachers, especially to help improve their practical language skills. The first wave of volunteers was small, but the program quickly became very popular. More and more families offered to house volunteers in their homes. The prospect of having a native speaker at the dinner table and being able to practice the language in everyday conversation was apparently very attractive. Particularly volunteers who were not only keen to tell locals about their own culture but were equally curious to learn about Georgian traditions proved very popular.

The experiment gathered momentum and became a big success. The third wave brought more than 2000 volunteers to Georgia. Every school in Georgia had at least one native speaker teaching English. The program was a key catalyst that helped establish English as a second language in 
Georgia. Previously, Russian had been the dominant second language. Georgian students have to take one mandatory exam in one out of five foreign languages: Russian, English, German, French, or Spanish. Before the reform, only 35 percent of students chose English. In 2012, 75 percent chose English, and the results were encouraging: 72 percent of students passed at $\mathrm{Bl}$ level. ${ }^{3}$

That said, self-improvement can sometimes go awry despite a student's best intentions and initiative. As it happens, a friend of mine, Niko, a Georgian monk, was very eager to improve his English language skills, especially his conversational ability.

"I can read and I can write, but I don't speak well. I'm just not fluent in English," he said.

"Why don't you go abroad for a while, to an English-speaking country? That's what I did, and after a few months, I was fluent," another friend suggested.

That's what Niko did. He went online and found a monastery in the United Kingdom that accepted foreign visitors. He made arrangements for an extended stay by email.

Six months later, we met again.

"How's your English, Niko?", I asked him in English, but he didn't answer and tried to change the subject. This made me even more curious.

"Did you even go to the UK?”, I asked, switching to Georgian.

"I did," he replied.

"What happened?"

"Well, I arrived in London. I took a bus, then another bus. The monastery was very hard to find, but eventually, I got there. But it turned out that all the monks there had taken a vow of silence. I ended up living in the UK for six months without hearing one word of English."

\subsection{University Reform - From Lenin to Clinton}

After the Rose Revolution, Georgia's tertiary education was in shambles. When Georgia was part of the Soviet empire, the focus was on Marxism, Leninism, and the history of the communist party. The only 
other area in which Georgian academics had some claim to excellence were natural sciences, such as physics, and mathematics. But all the best scientists had long left the country to take well-paid jobs abroad.

Many students were eager to study economics, but there was nobody who could have taught them. A few Marxists had tried to retrain themselves as international economists by reading Economics: Principles, Problems, \& Policies, by Campbell McConnell and Stanley Brue, the only economics book of note that was available in Russian translation at the time. But they were obviously out of their element, incapable of teaching business studies, finance, or contract law to a generation of aspiring young people who had their minds set on Wall Street. In fact, many of the students were more familiar with McConnell \& Brue than their lecturers.

\subsubsection{Degrees for Sale}

As a result of these shortcomings, corruption was the name of the game. The principal activity of Georgian academics in the mid-2000s was selling degrees to young people. This was, and partly still is, a prospering business that enriches heads of universities and departments, although their official salaries are in decline. This is because a university degree is almost obligatory as a status symbol in Georgia. Although this phenomenon is common in many other countries as well, it is especially pronounced in Georgia. It dates back to Soviet times, when being a university student would spare you the service in the Soviet army. Since Georgia was effectively occupied by the Soviet Union, the Soviet Army was perceived as a foreign force, and serving in it was perceived not as a service to Georgia. In fact, military service in the Soviet army was often a threat to a man's life because of the habitual brutalization of junior conscripts by their own commanders ("Dedovshchina," Russian for "reign of grandfathers"4). Because being a student offered some measure of protection from this cruel regime, Georgians became obsessed with academic credentials. The general perception was that a diploma was your only ticket to a good life, be it through a well-paid job or a rich spouse, and that young people who did not get a degree were a disgrace to their families. A university degree would also help you get promoted in a bureaucratic system that often relied on papers and stamps, rather than on merit and achievements. Because of the combined effect of these traditions and perceptions, universities made a fortune charging students for 
admission, good grades in end-of-year exams, and degrees. Preferential treatment in entrance exams was the most sought-after, and most costly service, which is why the centralization of these exams was such an important element of Georgia's education reform (see previous text).

\subsubsection{Partial Privatization and Scholarships}

While the centralization of entrance exams helped eradicate the biggest source of academic corruption, further attempts to reform Georgia's state-owned universities were less successful. Fresh blood should have been brought in by recruiting Georgian academics from abroad, but heads of universities and departments resisted such efforts in order to protect their staff from competition. In many ways, Georgia has not yet managed to reform its universities, much as it has largely failed to reform its justice system.

In other areas of tertiary education, however, Georgia made some progress. Some university facilities were privatized, and some new institutions offering higher education were launched, partly with financial support from the government. Today, almost 30 percent of all students in Georgia attend private universities, where the quality of education is much higher than at state-owned universities. This development encouraged many young people to study at the tertiary level.

To provide further encouragement, the government introduced scholarships for students who went abroad to pursue a master's degree. Any student admitted to one of the world's top 25 universities (according to rankings compiled by the Financial Times and USA Today) received a scholarship covering tuition, travel and accommodation. Acceptance into one of the top universities was the only criterion; the government did not require any additional assessments or exams. The program was open to students of engineering, natural sciences, and IT. In some years, business studies and law were also part of the program. The focus was on technical disciplines, because graduates in these fields were in short supply in Georgia at the time, and because the government perceived these subjects as the main drivers of Georgia's future economic development. Yet the scholarship itself was unconditional. It did not require graduates to come back and work for the Georgian government, or to come back to Georgia at all. When this aspect was publicized, the caliber of applicants improved significantly. The program was widely regarded as an important stepping 
stone on the way to a new, open-minded, hard-working elite that will eventually replace the communist intelligentsia in Georgia. Even if the country's tertiary education isn't yet fully reformed, a lot of young people are now highly motivated to study, work hard, and pursue a career that is based on merit, performance, and personal contribution, rather than on background, bribes, and connections.

\subsubsection{Matching Skills to Vacancies}

In the future, balancing the interests of students with the needs of the economy will be an important task for Georgia and countries in similar situations. Currently, the discrepancy between the skills of graduates and the requirements of the labor market is one of the biggest issues in tertiary education. Some studies say the number of unemployed people in the world roughly matches the number of vacancies at any given time. Many experts attribute this paradox to a mismatch of skills, although others contest this view. ${ }^{5}$ In any case, the perceptions and attitudes of different stakeholders in tertiary education are anything but aligned. University graduates feel that what they learn at universities is not, or not sufficiently, relevant to their future success in the real world. The vast majority of university lecturers, however, is convinced that most of their graduates are ready to be employed, while potential employers argue that only one-third of all graduates fulfill the requirements of the job market. According to some studies, universities that work closely with the private sector have a much better success rate when it comes to post-graduation employment.

Unfortunately, only a few institutions take this problem seriously. These are typically the world's top-ranking universities whose reputation depends, at least to a certain degree, on the employability of their graduates. In contrast, most other universities pursue more self-centered objectives, such as admitting as many students as possible, or offering a wide range of partly exotic disciplines, many of which are not relevant from the perspective of potential employers. These universities are providers of degrees, rather than matchmakers between students and employers.

Should universities teach whatever students are interested in, or should their primary goal be to prepare future generations for a life of fulfilling and gainful employment? And do teenagers really know what they want, let alone what is best for them? There are no easy answers 
to these questions. But imagine, just for the sake of argument, that ancient mythology became hugely popular among teenagers for one reason or another, and that thousands of teenagers chose to study Greek and Roman mythology. Would the job market be able to absorb so many mythology experts? If it weren't, would universities not be acting irresponsibly by admitting so many applicants into this discipline in the first place?

Most universities are simply trying to make money, and they will offer whatever courses help them maximize their proceeds. If students demand mythology, and are willing to pay for it, universities will teach it, especially since many such exotic disciplines are much less costly to teach than, say, medicine or chemistry. An aspiring doctor needs a training hospital, and an aspiring chemist still needs a lab. In contrast, all a budding mythologist needs is a few books. ${ }^{6}$ This applies even to state-funded universities, where students don't pay for tuition themselves, or at least not in full. As long as someone, be it an individual or the government, provides funds for every registered student, universities will continue to cater to the whims of applicants. Maybe there is a deficiency in this system, and perhaps tweaking university financing in a small way would help push the system toward a more efficient structure.

For example, the government could provide additional financing, e. g., in the shape of bonuses, to those universities whose graduates achieve the highest average employment rate. Alternatively, the government could introduce regulation that allows universities to charge students for services provided not only during their education, but also during the first few years of employment, based on their income. For instance, a certain percentage of the income tax graduates pay during the first two to three years after graduation could go directly to the university they graduated from. Such a system would help decrease tuition fees during the study period, when many students have little money to spare. What is more, it would increase the motivation of universities to find jobs for their graduates, be it by adjusting the number of places in a given discipline or by offering placement services for all those mythologists. Universities would work closely with potential employers to make sure their graduates have what it takes to succeed in the job market. During a transition period, the government could provide special financing to help prevent certain disciplines from dying out, even if graduates in these fields don't have the best 
employment prospects. This would help ensure that universities remain centers of culture and research. Certain institutions, such as arts colleges, musical conservatories, or pure research facilities, will require an altogether different financing formula. Compare the discussion in the previous chapter on healthcare facilities that are not commercially viable, but necessary to ensure comprehensive medical services for the population.

While such a structural reform of university financing has not yet been implemented in Georgia, it could be a game changer for tertiary education, both in Georgia and in other countries around the world.

\subsubsection{An American University in Georgia}

To help transform Georgia's tertiary education system, the government devised various lighthouse projects. Bringing an American university to Georgia was, perhaps, the most prominent of these projects. To establish an American university in Georgia, the government of Georgia signed a contract with the Millennium Challenge Corporation (MCC) a U.S. initiative that allocates grants to developing countries with a proven track record of promoting democracy and human rights. Almost all countries that have received these funds have spent them on infrastructure projects, such as roads, bridges, and water utilities, as Georgia had done with the first tranche of financing. But the government decided that the second tranche of the grant should be used to promote higher education specifically, to establish an American university for technological studies in Georgia. Governments in other countries have pursued similar concepts in the past, but few of them have succeeded. The principal difference between this initiative and projects developed elsewhere is that this project is financed by the United States, not by funds derived from the exploitation of natural resources in the hosting state. A university based in the United States and selected through a tender process will be given sole responsibility for managing the university in Georgia. The government has no intention, nor will it be allowed, to intervene in any decision making. The degrees awarded by the American university in Georgia will be equivalent to those awarded by the parent institution in the United States. Effectively, the Georgian institution will be a satellite campus of the U.S. university. At the time of writing, the project is under development. 
On a personal note, let me relate the story of how high-level support for this project was secured. That day, everybody was a bit nervous. People were running around, arranging and re-arranging chairs, tables, bottles of water, everything. We were expecting the U.S. Secretary of State Mrs. Hillary Clinton to discuss various aspects of Georgian-American relations: financial assistance, free trade, defense co-operation. My idea and my mission was to get Mrs. Clinton to green-light funding for tertiary education reform. At the time, Georgia had already received and spent a first tranche. Yet I was painfully aware that we were not succeding to reform the tertiary education system, one of my biggest personal regrets. The privatization of the Georgian Agrarian University and establishing of the Free Unversity (both by private investor - Kakha Bendukidze) were the only real success stories at the time. Establishing an American university in Georgia was a long shot, but I went for it anyway.

I was relieved to find that Mrs. Clinton was a much more genial person than you would think from seeing her on TV, that she was in a good mood, and that she clearly liked Georgia. My turn came and I pitched the idea of an American university in Georgia. I explained that, although I have a business degree myself, the focus should be on IT and engineering, the disciplines that I thought were most in need to develop Georgia's economy. Part of the funds from the MCC would be used to establish the university, while the rest would go to the best students in the form of scholarships. The university would be under U.S. management and award U.S. degrees.

"But there are some universities like this in the region, and some of them are not very successful," said Mrs. Clinton.

She was right, and I was prepared for her objection. I moved on to the next part of my presentation. I explained that the issue at these universities is the fact that the local government often meddles with decisions regarding staffing or the curriculum. In contrast, we would make the independence of the university's management an explicit condition of MCC financing to protect it from future attempts at interference.

"But do you think you will be able to attract a high-level U.S. university?"

This was her second question with negative connotation. One more - and the project would be dead. I admitted that a lot of U.S. universities were understandably afraid to take high risks in small, developing countries. But in this case, it would be different: a project led by the U.S. government and backed by U.S. financing, a one of a kind effort to bring Western 
excellence to a developing country. It would provide unparalleled opportunities to those who can least afford a good education, but who need it the most: the poor. It would be a fully merit-based enterprise. I made quite a speech. Everybody liked it. Our president nodded with satisfaction, and Mrs. Clinton looked like she was very much on board, especially after the last few sentences. We were all eagerly awaiting her verdict.

"But," she began.

I took a chance and interrupted her. If she finished this sentence, it would be over. I had run out of prepared arguments. I had to think up something new on the spot.

"Imagine, Madam Secretary," I started, not even knowing where I was going with this, "imagine a regional champion, a center for education and science, a center for scientific research and development. We still have some good scientists left in the region, and they are looking for a home. Not only Georgian students will be attending the American university. It will attract students from neighboring countries as well. Imagine, Madam Secretary, that, 20 years from now, the presidents of Armenia and Azerbaijan will have graduated from this University as classmates. Wouldn't that be something?"

Silence. She smiled and nodded. The project was approved a few months later. Georgia received a grant of USD 150 million.

\section{Notes}

1. J.D. Salinger, The Catcher in the Rye, Little, Brown, and Company, New York, 1951 (Salinger 1951).

2. http://data.worldbank.org/indicator/SE.PRM.ENRL.TC.ZS/countries? page $=1 \&$ display $=$ default (retrieved in May 2016).

3. According to the Common European Framework of Reference for Languages, $\mathrm{Bl}$ is the third out of six levels of proficiency (Al to C2). Bl is defined as follows: "Can understand the main points of clear standard input on familiar matters [...]. Can deal with most situations likely to arise whilst travelling in an area where the language is spoken. Can produce simple connected text and $[\ldots]$ describe experiences [...]." http:// www.coe.int/t/dg4/linguistic/Source/Framework_EN.pdf (retrieved in May 2016).

4. https://www.hrw.org/reports/2004/russial004/6.htm (retrieved in May 2016). 
5. See Horst Entorf, Mismatch Explanations of European Unemployment: A Critical Evaluation, Springer Science \& Business Media, 2012 (Entorf 2012).

6. In Germany, for example, a university education in medicine costs the government approximately EUR 200,000, more than 15 times the cost of an education in the humanities: http://www.saarbruecker-zeitung.de/alte_inhalte/ universitaet-des-saarlandes/art298914, 3848035 (retrieved in May 2016).

Open Access This chapter is distributed under the terms of the Creative Commons Attribution 4.0 International License (http://creativecommons.org/licenses/by/4.0/), which permits use, duplication, adaptation, distribution and reproduction in any medium or format, as long as you give appropriate credit to the original author(s) and the source, provide a link to the Creative Commons license and indicate if changes were made.

The images or other third party material in this chapter are included in the work's Creative Commons license, unless indicated otherwise in the credit line; if such material is not included in the work's Creative Commons license and the respective action is not permitted by statutory regulation, users will need to obtain permission from the license holder to duplicate, adapt or reproduce the material.

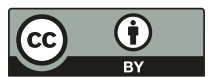

